\title{
Effects of health education programme on teenagers with premenstrual syndrome
}

\author{
Amina Ather \\ From EPMA-World Congress 2013 \\ Brussels, Belgium. 20-21 September 2013
}

\section{Introduction}

An health education programme was evaluated to determine its efficacy in increasing knowledge about menstrual cycle and management of premenstrual syndrome (PMS) though home remedies with simple kitchen herbal recipes, diet control and breathing exercise along with education of anatomy and physiology or female reproductive system. As calculated approx 6 in 10 women in Europe suffer from PMS where as in India the rate of PMS is at higher level, 159,760,591 against 1,065,070,607 populations which is 9 in 10 [1]. With the highest adolescent population in India, the real challenge for the nation is to provide nutritional health and educational needs for this segment of the population, particularly girls, according to the recent report released by UNICEF [2]. In India one-third adoles- cent girls are under nourished. Survey reports indicate an approximation of $56.2 \%$ of girls to be under nourished and the rate of literacy to be $53.87 \%$, thus indicating considerable 'unmet needs' in terms of education, health and nutrition [3].

\section{Aim}

To assess the effectiveness of structured teaching program on knowledge, attitude and practice regarding, premenstrual syndrome and its management among teenagers in high school at Bangalore.

\section{Objectives}

To assess the knowledge regarding premenstrual syndrome among teenagers in terms of pre-test score and

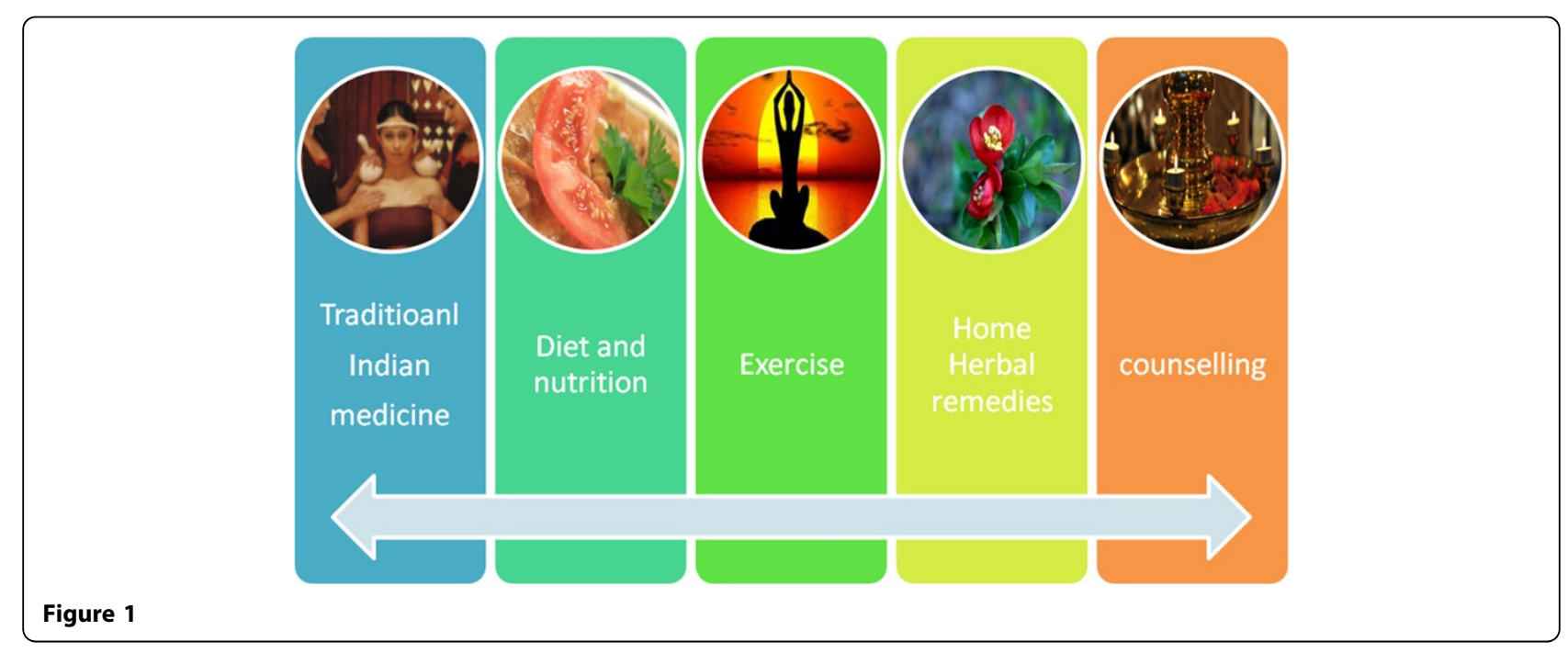

Correspondence: atheramina@gmail.com

Medizin Park Ruhr, Castrop-Rauxel, Germany

(c) 2014 Ather; licensee BioMed Central Ltd. This is an Open Access article distributed under the terms of the Creative Commons Attribution License (http://creativecommons.org/licenses/by/2.0), which permits unrestricted use, distribution, and reproduction in any medium, provided the original work is properly cited. The Creative Commons Public Domain Dedication waiver (http:// creativecommons.org/publicdomain/zero/1.0/) applies to the data made available in this article, unless otherwise stated. 
to evaluate the effectiveness of structured teaching programme by comparing pre-test and post-test score along with it to find out the association between score of knowledge, attitude and practice and the selected demographic variables.

\section{Method}

Subjects consisted of students (experimental group: 2134, control group: 2134). The experimental group participated in a PMS nutritional education program for 8 weeks (including group and individual involvement). Data was collected before and after the education, and measurement tools were premenstrual symptoms, PMS knowledge, and self health behaviour.

\section{Results}

After the intervention, the experimental group showed a significant increase in PMS knowledge $(\mathrm{Z}=6.32, \mathrm{p}=.000)$ and self health behavior $(\mathrm{t}=3.00, \mathrm{p}=.004)$ compared to the control group. After the intervention the experimental group showed a significant increase in PMS knowledge $(\mathrm{Z}=-4.64, \mathrm{p}=.000)$ and self health behavior $(\mathrm{t}=-3.04$, $\mathrm{p}=.005)$ than before the intervention.

\section{Conclusions}

These results suggest that the short term effects of a PMS nutritional education programme for teenagers (Studying in Bangalore district) was proven useful and the program should be applied to PMS nutrition education for PMS clients as well as health professionals.

\section{Recommendations}

Individual health assessment and counselling along with home herbal remedies, diet chart, exercise and religious counselling for prevention of PMS among teenagers.

Published: 11 February 2014

References

1. Nations challenge to provide nutritional health and education. Indian Express New Delhi; 2011.

2. Markens S: The Problematic of 'Experience': A Political and Cultural Critique of PMS. Gender Society 1996, 10(1):42-58.

3. Figert AE: The Three Faces of PMS: The Professional, Gendered, and Scientific Structuring of a Psychiatric Disorder. Social problems 1995, 42(1):56-73.

doi:10.1186/1878-5085-5-S1-A158

Cite this article as: Ather: Effects of health education programme on teenagers with premenstrual syndrome. EPMA Journal 2014 5(Suppl 1): A158.
Submit your next manuscript to BioMed Central and take full advantage of:

- Convenient online submission

- Thorough peer review

- No space constraints or color figure charges

- Immediate publication on acceptance

- Inclusion in PubMed, CAS, Scopus and Google Scholar

- Research which is freely available for redistribution

Submit your manuscript at www.biomedcentral.com/submit 